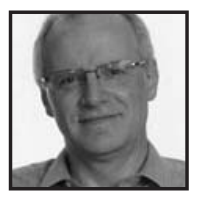

\title{
Evidence in Education
}

\section{Ben Levin, Ontario Institute for Studies in Education, University of Toronto}

\begin{abstract}
How much can we reasonably expect from research in education? There are many reasons to think the effects could be both powerful and positive. The call to make more use of research evidence does not in any way conflict with professional autonomy; if anything, it reinforces it. There are many areas of education where we do not have enough evidence to be confident about what to do. However, there are areas where we do have enough knowledge and yet are not applying it broadly. The take-up of evidence greatly depends on professionals' belief that their work should be guided by reliable knowledge, yet that belief is itself largely created by social practices and communication patterns. Many of the necessary elements to do so are simply not there today in most schools or school systems. Many of these features could be reinforced with relatively little effort with good results for students.
\end{abstract}

\footnotetext{
o what extent is public education an activity grounded in solid evidence? To what extent can it be such an activity, and what would be required for this to be the case?
}

My career has been about half as a university professor and researcher, and half in government working on issues of education policy. From the start of my active involvement in education, which goes back to when I was a high school student trying to give students a stronger voice in our education, I was struck by the degree to which policy and practice in schools seemed to be based on people's own experience and opinions, whether well founded or not, on what children needed or were like. From that day to this - now four decades - I have been involved in efforts to connect research knowledge about education to what happens in schools. I have done that 
work in universities, in government, in school districts and in third-party organizations. In the last few years my academic work at Ontario Institute for Studies in Education (OISE) has focused very largely on this connection, now sometimes called "knowledge mobilization."1

Looking back at these efforts is in some ways encouraging and in other ways depressing.

Let's start with the encouraging side. First, the interest in and respect for research among professional educators has grown immensely. Twenty years ago a group of professional educators would greet the term "education research" with distinct lack of interest, if not derision. Today, while educators continue to have many criticisms of education research, almost all educators believe that research does have important contributions to make to what we know and what we should do in schools.

This change is not just rhetorical. Just as new evidence influences public behaviour in areas such as health or diet, new information about effective practice in education is of interest to the education profession. And some practices in education have changed, driven at least in part by evidence. For example, corporal punishment has been eliminated from schools with support from research showing its negative impact. Streaming of students has been reduced for similar reasons. Some students with disabilities are much better educated due to more research on their capacities and ways of addressing them. Teaching of reading has changed to emphasize new research on balanced literacy.

The growing impact of research in these and other cases results from several factors. The first is increasing research knowledge. There are more areas of education in which we have enough good research to be reasonably confident that we know or understand what to do-in areas as diverse as early reading, student motivation, parent engagement, impacts of staff development, and others. Of course, there is a great deal more to learn, but we know a reasonable amount now in a range of areas. Moreover, especially in the last few years, there have been increasing efforts to move that knowledge from its original academic form to other forms more likely to be attended to by educators. There are more, and better, syntheses of research, and more, and better modes of sharing research information whether through Web sites, documents, conferences, videos, coaching, learning communities, or other means. 
But the supply of research only matters insofar as there is demand for it, and demand has also been increasing. One reason is increasing levels of education among educators, including many with graduate degrees. Another is more effective advocacy by third parties seeking to have particular policies or practices adopted in schools that use research as one of their supporting grounds. Evidence from research is routinely sought out and used by advocacy groups of various kinds and, as a result, has more public prominence. Although some advocacy groups are looking for research to advance a pre-determined position, not all third parties take this stance. Organizations such as associations of teachers of various subjects, or national bodies such as the Canadian Education Association, or interest groups such as learning disability associations tend to begin with a commitment to follow the evidence wherever it leads.

That is the optimistic side. However, there is also a pessimistic picture that applies to both the supply and demand sides of education research.

The picture here is that education research in Canada - and internationallycontinues to be poorly funded, small scale, and does not have enough replication and cumulation of knowledge (OECD, 2007). There are few large-scale programs of research. Canada simply does not have enough people who have strong research skills and understand education policy and practice deeply in a way that allows the right connections to be made. We have nothing in education like the strong efforts in health by the Canadian Institutes for Health Research to build strong links between research, policy and practice.

Moreover, even if we had much more compelling research, Canadian school systems, again like those in other countries, lack the organized capacity to find, share and use that research (Levin, 2008a). Very few school systems have people, processes or systems related to research use. By this I mean that few school systems have routines that bring research to people's attention on a regular basis, or make research results a normal focus of discussion or consideration. This is not just true of schools and school districts; few ministries of education have an infrastructure to support research either. So the rhetoric about the importance of education is not (yet) matched by the steps needed to give evidence a rightful place.

How much can we reasonably expect from research in education? There are many reasons to think the effects could be both powerful and positive. Education is unique among professions in its view that each person can and should find his or her own way, and that standard practices are something to be eschewed. Every other 
profession, whether lawyers, nurses, engineers, architects or even airplane pilots, regards standard practices supported by evidence as the core of what it means to be a professional. Professional preparation largely consists of learning when and how to use standard practices as well as how to exercise professional judgment as to their applicability. Standard practices are not seen as infringement on professional autonomy, but are viewed as a repertoire that allows professionals to focus on those areas where their judgment is required. Yet schools resist the whole idea that there should be things that virtually all teachers do in the same way, or all schools do in the same way.

Parenthetically, this resistance has not stopped school systems from insisting that all teachers adopt practices that may lack empirical warrant. Educators are all too familiar with the frequent faddism in school systems that adopt one or another package promoted by some entrepreneur, only to drop it a few years later. That faddism is one reason why teachers and school leaders are resistant to new change proposals. It is also a reason that educators always have to be thoughtful about their practice. Educating can never be reduced to rote just as students' learning should never be rote. The call to make more use of research evidence does not in any way conflict with professional autonomy; if anything, it reinforces it.

There are many areas of education, as already noted, where we do not have enough evidence to be confident about what to do. However, there are areas where we do have enough knowledge and yet are not applying it broadly. A couple of examples can illustrate. One would be failure and grade repetition. Very large numbers of students end up repeating courses or grades during their schooling. In Canada about $30 \%$ of students do not finish high school "on time." This means that literally hundreds of millions of dollars are being spent so that students can repeat courses or years. Although many people still think failure teaches important life lessons, one of the strongest findings in psychology is that failure depresses future effort (National Research Council, 2003). So the research says that we should do everything we can to prevent failure, as this will bring better results in the long term. Such an approach is far from standard practice in most school systems.

Take a second example-student motivation. We have a lot of evidence on the kind of practices that students find motivating (an excellent summary is in National Research Council, 2003). These are pretty similar to what motivates adultsworthwhile tasks, some autonomy in how to do them, good feedback, good colleagues to work with, opportunities to learn and improve. These features lead to more effort and better results. Yet to a large extent these principles are not common 
practice in schools. Recent Canadian evidence (Willms et al., 2009), as well as international evidence from PISA (Willms, 2003), shows how few students in secondary schools report high levels of engagement with their schooling.

In both these instances there is potential for large improvements in educational outcomes through wider application of current knowledge. However, getting that application is not a simple matter. Substantial research (e.g., Mitton et al., 2007; Nutley et al., 2007) also shows how difficult it is to get people to change their practices, even when the changes are widely understood to be desirable and fairly easy to do. For example, it is very difficult to get hospital staff to wash their hands consistently (Gawande, 2007) even though people know this is important and know how to do it. It is much harder to change complex practices such as teaching.

Yet we also know something about how such changes happen. Change in organizational practices requires both will and skill (Levin, 2008b). It certainly takes more than telling people. While we often think of change in schools as being a matter for individual teachers, it is really much more a matter of altering social conditions in ways that support new behaviour. The take-up of evidence greatly depends on professionals' belief that their work should be guided by reliable knowledge, yet that belief is itself largely created by social practices and communication patterns. Many of the necessary elements to do so are simply not there today in most schools or school systems. These elements include constant repetition of key messages, systems and processes for educators to learn about and discuss research findings, opportunities to practice new strategies with coaching and feedback, and good evidence that new practices produce better results.

Many of these features could be reinforced with relatively little effort. It is possible to add the discussion of research findings to meeting agendas, to share key research messages regularly, and to gather and share evidence on current practices without huge efforts, yet each of these steps would change the climate around the use of research and evidence. Of course there are other, larger steps that would support a profession with a stronger base in solid evidence, but the point to be made here is that every teacher or education leader can do something to move the system in this direction, with good results for students. 


\section{Note}

1. See www.oise.utoronto.ca/rspe for more information on my team's current program of research.

\section{References}

Gawande, A. (2007). Better. London: Picador.

Levin, B. (2008a). Thinking about knowledge mobilization, produced by the Canadian Council on Learning and the Social Sciences and Humanities Research Council of Canada. Retrieved May 18, 2010, from www.oise.utoronto.ca/rspe/ Conference_Presentations_Publications/i ndex.html

Levin, B. (2008b). How to change 5000 schools. Cambridge, MA: Harvard Education Press.

Mitton, C., Adair, C. E., McKenzie, E., Patten, S. B., \& Perry, B.W. (2007).'Knowledge transfer and exchange: Review and synthesis of the literature', The Milbank Quarterly, 85(4), 729-768.

National Research Council (2003). Engaging schools: Fostering high school students' motivation to learn. Washington, D.C.: National Academies Press.

Nutley, S., Walter, I., \& Davies, H. (2007). Using evidence: How research can inform public services. Bristol:The Policy Press.

OECD (2007). Knowledge management: Evidence and education: Linking research and practice. Paris: OECD Publications Service.

Willms, J.D. (2003). Student engagement at school: A sense of belonging and participation. Paris: Organization for Economic Cooperation and Development.

Willms, J.D., Friesen, S., \& Milton, P. (2009). What did you do in school today? First national report. Toronto: Canadian Education Association. 


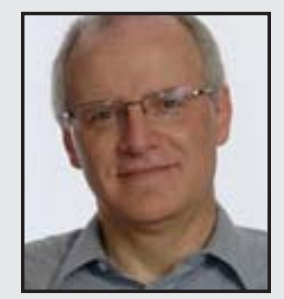

Ben Levin is a Professor and Canada Research Chair in Education Leadership and Policy at the Ontario Institute for Studies in Education, University of Toronto. He has spent half his career as an academic and the other half as a senior civil servant. He has served twice as Deputy Minister of Education for the Province of Ontario and, from 1999 through 2002, was deputy Minister of Advanced Education and Deputy Minister of Education, Training and Youth for the Province of Manitoba. $\mathrm{He}$ is a native of Winnipeg and a graduate of the University of Manitoba, Harvard University and OISE. In addition to building an academic and research career, Dr. Levin has worked with private research organizations, school districts, provincial governments, and national and international agencies. He has published five books, most recently, How to Change 5000 Schools, and more than 200 other articles on education. His current interests are in large-scale change, poverty and inequity, and finding better ways to connect research to policy and practice in education.

\section{LINK TO:}

http://home.oise.utoronto.ca/ blevin/ 